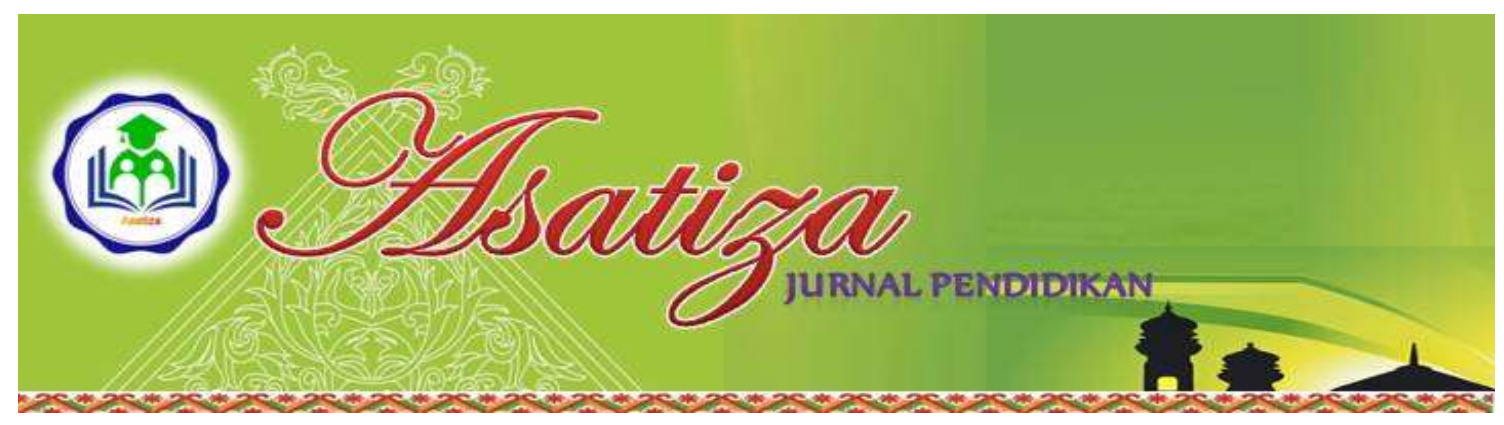

\title{
MINAT MAHASISWA DALAM MENGHADIRI KEGIATAN SEMINAR PROPOSAL DI SEKOLAH TINGGI AGAMA ISLAM AULIAURRASYIDIN TEMBILAHAN KABUPATEN INDRAGIRI HILIR Maskanah $^{1}$
}

\author{
${ }^{1}$ Mahasiswi Prodi PAI STAI Auliurrasyidin Tembilahan, Indonesia
}

\begin{abstract}
Abstrak
Penelitian ini bertujuan untuk mengetahui minat mahasiswa dalam menghadiri kegiatan seminar proposal itu sangat penting bagi mahasiswa. Menghadiri seminar ini, tidak ada unsur paksaan dan atas keinginan sendiri.

Populasi dalam penelitian ini adalah seluruh Mahasiswa STAI Auliaurrasyidin Tembilahan yang telah mengikuti matakuliah metodologi penelitian yang berjumlah 1153 mahasiswa dengan sampel sebanyak 92 orang. Teknik pengumpulan data yang digunakan adalah angket, wawancara serta dokumentasi. Sedangkan teknik analisa data yang digunakan dalam penelitian ini adalah teknik analisa deskriptif kuantitatif dengan menggunakan rumus porsentase.

Berdasarkan penelitian dan analisa data yang peneliti peroleh melalui rekapitulasi angket, diperoleh hasil bahwa minat mahasiswa dalam menghadiri kegiatan semiar proposal di STAI Auliaurrasyidin Tembilahan dikategorikan "baik" karena mencapai angka perentasi 66,67 yaitu terletak pada interval 61-80\%.
\end{abstract}

Kata Kunci: Minat, Menghadiri, Seminar Proposal

\section{A. PENDAHULUAN}

\section{Latar belakang}

Setiap lembaga yang menyelenggarakan pendidikan mengharapkan output dari pendidikan yang dilaksanakannya berkualitas dan memiliki daya saing yang tinggi oleh sebab itu setiap lembaga pendidikan mempunyai strategi untuk meningkatkan kualitas pendidikannya.

Pendidikan adalah salah satu bentuk perwujudan kebudayaan manusia yang dinamis dan syarat perkembangan. Perubahan atau perkembangan pendidikan adalah hal yang memang seharusnya terjadi sejalan dengan perubahan budaya kehidupan. Perubahan dalam arti perbaikan pendidikan pada semua tingkat perlu terus menerus dilakukan sebagai antisipasi kepentingan masa depan.

Pendidikan yang mampu mendukung kepentingan dimasa mendatang adalah pendidikan yang mampu mengembangkan potensi peserta didik, sehingga yang bersangkutan mampu menghadapi dan memecah problema kehidupan yang dihadapinya. Pendidikan harus menyentuh potensi nurani maupun potensi kompetensi 
peserta didik. Konsep pendidikan tersebut terasa semakin ketika seseorang harus memasuki kehidupan di masyarakat dan dunia kerja, karena yang bersangkutan harus mampu menerapkan apa yang dipelajari disekolah untuk menghadapi problema yang dihadapi dalam kehidupan sehari-hari saat ini maupun yang akan datang. ${ }^{1}$

Salah satu kegiatan akademik yang terdapat di perguruan tinggi adalah seminar. Seminar biasanya diadakan oleh organisasi yang ada didalam kampus ataupun diselenggarakan oleh pihak kampus. Seminar yang diadakan oleh pihak kampus adalah seminar proposal penelitian, dimana seminar proposal penelitian ini diwajibkan kepada seluruh mahasiswa yang telah mempelajari metodologi penelitian pada semester VI untuk menyelesaikan tugas akhir berupa skripsi.

Kegiatan seminar proposal biasanya mempunyai aturan sendiri di setiap perguruan tinggi, penyeleng garaan kegiatan seminar proposal tergantung bagaimana peraturan yang sudah ditetapkan diperguruan tinggi tersebut. Pada dasarnya perguruan tinggi mempunyai kebebasan untuk menetapkan peraturan kegiatan seminar proposal sesuai dengan standar kemampuan mahasiswa dan dosen pembimbing yang menjadi pelaksana kegiatan seminar proposal.

Namun permasalahan sebenarnya bukanlah terletak kepada peraturan pelaksanaan kegiatan seminar proposal yang sudah di tetapkan pada perguruan

${ }^{1}$ Trianto, Mendesain Model Pembelajaran Inovatif-Progresif (Jakarta: Kencana Prenada Media Group, 2011), h. 1-2 tinggi, tetapi terletak kesadaran mahasiswa untuk menghadiri kegiatan seminar proposal tersebut.

Proposal penelitian ini merupakan salah satu syarat dalam menyelesaikan tugas bagi mahasiswa STAI Auliaurrasyidin Tembilahan yang harus di laksanakan. Mahasiswa yang akan melaksakan tugas akhir harus menghadiri seminar proposal terlebih dahulu, dengan tujuan mahasiswa dapat mengambil pelajaran dari mengikuti kegiatan seminar proposal, selain dari itu seminar proposal adalah sebagai sarana pendidikan bagi mahasiswa untuk memperluas wawasan, kesempatan berkonsultasi dalam mencari pemecahan masalah secara ilmiah.

Menurut Adnan Mahdi dan Mujahidin dalam Bukunya Panduan Penelitian Praktis Untuk Menyusun Skripsi, Tesis dan Disertasi menyebutkan bahwa yang di maksud dengan seminar proposal adalah:

Seminar proposal merupakan salah satu kegiatan yang dikhususkan untuk membahas rencana penelitian yang telah di susun oleh mahasiswa. Kegiatan seminar ini biasanya di jadwalkan oleh program studi atau jurusan setelah semua persyaratan seminar dipenuhi oleh mahasiswa. $^{2}$

Tujuan dari kegiatan seminar proposal ini adalah untuk mendengarkan rencana penelitian mahasiswa, kemudian didalami dengan mengajukan pertanyaan seputar isi proposal,serta memberi masukan dan arahan agar mahasiswa

${ }^{2}$ Adnan Mahdi \& Mujahidin, Panduan Penelitian Praktis Untuk Menyusun Skripsi, Tesis, dan Disertasi, (Bandung: Alfabet, 2014), h. 41 
dengan mudah melanjudkan rencana penelitiannya. $^{3}$ Selain dari itu tujuan dari menghadiri kegiatan seminar itu sendiri yaitu untuk mendapatkan gambaran bagaimana sebenarnya pelaksanaan seminar proposal, keikut sertaan mahasiswa sebagai peserta seminar akan memberikan pemahaman lebih bagi mahasiswa, dan khusus untuk mahasiswa yang belum melakukan seminar akan menjadi acuan dalam kegiatan yang akan di lakukan nantinya dan mahasiswa yang telah melakukan seminar ini sebagai pengetahuan saja dan mempermudah jalannya penyusunan karya ilmiah. ${ }^{4}$

Ketika Kegiatan seminar proposal yang akan dilaksanakan, penyeminar terlebih dahulu mempresentasikan apa yang ada didalam isi proposal penelitian yang telah dibuatnya, dan kewajiban dari para Peserta seminar atau yang menghadiri seminar adalah mengkritisi isi proposal penyeminar yang bersangkutan dengan cara memberikan masukan atau pun memberiakan saranterhadap isi proposal, oleh sebab itu kegiatan seminar proposal adalah sebagai sarana bagi mahasiswa untuk mengaktualisasikan dirinya dan berkomunikasi secara efektif dan efesien.

Namun pemikiran itu terbantahkan dengan kenyataan yang terjadi dilapangan, seperti studi pendahuluan yang telah penulis lakukan di Sekolah Tinggi Agama Islam Auliaurrasyidin Tembilahan, dimana peserta seminar proposal terkadang sangat susah untuk mencari peserta yang ingin menghadiri

\section{${ }^{3} \mathrm{I}$ bid,}

${ }^{4}$ Ibid., h.42 seminar, padahal seluruh mahasiswa sudah mengetahui jadwal seminar proposal yang sengaja dituliskan di papan tulis yang berada tepat di depan ruangan seminar proposal.

Pada umumnya peserta seminar yang menghadiri kegiatan seminar proposal adalah mahasiswa dari kelas yang sama dan prodi yang sama, tetapi tidak menutup kemungkinan mahasiswa yang lainnya dengan lokal yang berbeda untuk mengadirinya. Mahasiswa yang menjadi peserta dalam kegiatan seminar proposal biasanya diminta oleh mahasiswa penyeminar untuk menghadiri kegiatan seminar proposal.

Selain dari itu ada beberapa mahasiswa yang menjadi peserta seminar, dimana peserta seminar itu yaitu mahasiswa yang telah mempelajari metodologi penelitian, hanya untuk melengkapi persyaratan untuk pengajuan proposal penelitian mahasiswa yang mengajukan proposal harus memiliki bukti telah menghadiri kegiatan seminar proposal minimal sebanyak tujuh kali yang telah ditanda tanggani oleh pembimbing peserta seminar yang bersangkutan.

\section{Pengertian Minat}

Menurut kamus lengkap bahasa Indonesia minat adalah keinginan yang kuat, gairah kecendrungan hati yang sangat tinggi terhadap sesuatu. ${ }^{5}$ Minat dalam bahasa Inggrisnya Interest ${ }^{6}$ dalam bahasa Arabnya Ihtimaam. ${ }^{7}$ Dapat

${ }^{5}$ Tim Prima Pena, Kamus Lengkap Bahasa Indonesia, (Gita Media Press, T. Th), h.450

${ }^{6}$ Jhon M. Echols dan Hasan Shadily, Kamus Inggris Indonesia, (Jakarta: PT. Gramedia, 2000), h.327

${ }^{7}$ M. Kasir Ibrahim, Kamus Arab, (Surabaya: Apollo, t.th), h. 581 
diartikan sebagai suatu kecendrungan untuk memberikan perhatian dan bertindak terhadap orang, aktivitas, atau situasi yang menjadi obyek dari minat tersebut dengan disertai perasaan senang. Bahasa tersebut terkandung suatu pengertian bahwa di dalam minat ada pemusatan perhatian subyek, ada usaha untuk mendekati, mengetahui, memiliki, menguasai, atau berhubungan dari subyek yang dilakukan dengan perasaan senang, ada daya penarik dari obyek. ${ }^{8}$

Minat merupakan kecendrungan untuk selalu memperhatikan dan mengingat sesuatu terus-menerus yang sangat erat hubungannya dengan perasaan senang. Orang yang berminat terhadap sesuatu karena ia menyukai nya dan memiliki sikaf positif terhadap sesuatu tersebut. ${ }^{9}$

Beberapa pengertian minat di atas dapat peneliti simpulkan beberapa hal penting tentang minat yaitu:

a. Minat merupakan bagian dari aspekaspek psikologis atau kejiwaan seseorang.

b. Minat sebagai bagian dari aspek psikologis seseorang yang menampak kan diri pada bermacam-macam gejala, seperti perasaan senang, kecendrungan hati atau ketertarikan, keinginan, kesukaan, gairah, perhatian, kesadaran seseorang akan

${ }^{8}$ Abdul Rahman Shaleh dan Muhbib Abdul Wahab, Psikologi Suatu Pengantar dalam Perspektif Islam, (Jakarta: Prenada Media, 2004), h. 263

${ }^{9}$ Psikologi, Modul Orientasi Pembekalan Calon Pns, Proyek Pembibitan Calon Tenaga Kependidikan Biro Kepegawaian Secretariat Jendral Departemen Agama Republik Indonesia Tahun 2004, h.48 pentingnya sesuatu, rasa ingin tahu tentang sesuatu, partispasi.

Setiap individu mempunyai kecendrungan fundamental untuk berhubungan dengan sesuatu yang ada dalam lingkungannya. Apabila sesuatu itu memberikan kesenangan kepada dirinya, kemungkinan seseorangakan berminat terhadap sesuatu itu. Jadi dapat dikatakan bahwa minat ini terkait dengan usaha. Semisal Seseorang menaruh minat pada pelajaran PAI, tentu ia akan berusaha semaksimal mungkin untuk menguasainya, sebaliknya orang yang kurang berminat, ia tidak akan berusaha bahkan akan mengabaikannya.

Menurut Marksheffel yang di terjemahkan oleh Ibrahim Bafadal minat dapat di jelaskan sebagai berikut:

a. Minat bukan hasil pembawaan manusia tetapi dapat di bentuk atau di usahakan, dipelajari, dan di kembang kan.

b. Minat itu bisa di hubungkan untuk maksud-maksud tertentu untuk tindakan.

c. Secara sempit minat di asosiasikan dengan keadaan sosial seseorang dan emosi seseorang.

d. Minat itu biasanya membawa inisiatif dan mengarah kepada kelakuan atau tabiat manusia. ${ }^{10}$

Minat merupakan suatu pemusatan perhatian secara tidak sengaja yang muncul dengan penuh kemauan, rasa ketertarikan, keinginan dan kesenangan. Ciri-ciri umum minat ialah perhatian dan harapan yang besar, beroreantasi pada keberhasilan mempunyai kebanggan,

${ }^{10}$ Ibrahim Bafadal, Pengelolaan Perpustakaan Sekolah, (Jakarta: Bumi Aksara, 2014), h.192 
kesediaan untuk berusaha dan mempunyai pertimbangan yang positif. ${ }^{11}$

Menurut Slameto dalam bukunya Belajar dan Faktor-Faktor yang Mempengaruhinya,minat adalah rasa lebih suka dan rasa keterikatan pada suatu hal atau aktivitas, tanpa ada yang menyuruh. $^{12}$ Seseorang orang yang berminat terhadap aktivitas akan memperhatikan aktivitas itu secara konsisten dengn rasa senang. ${ }^{13}$ Minat pada dasarnya dalah penerimaan akan sesuatu hubungan antara diri sendiri dengan sesuatu di luar diri. Semakin kuat atau dekat dengan hubungan tersebut semakin besar minat. Suatu minat dapat di ekspresikan melalui suatu pernyataan yang menunjukkan bahwa seseorang lebih menyukai suatu hal, dari pada hal lain, dapat pula di manisfasikan melalui partisifasi dalam suatu aktivitas. ${ }^{14}$

Menurut Safari dalam bukunya Penulisan Butir Soal Berdasarkan Penilaian Berbasis Kompetensi menyebutkan bahwa minat belajar adalah pilihan kesenangan dalam melakukan suatu kegiatan dan dapat membangkitkan gairah seseorang dalam memenuhi kesediaan dalam belajar. Untuk mengetahui minat belajar bisa diperoleh dari tes minat belajar mengukur beberapa aspek antara lain: ${ }^{15}$

\footnotetext{
${ }^{11}$ Sumanto, psikologi umum, (Yogyakarta:PT buku seru,2014), h.161

${ }^{12}$ Slameto, Belajar dan Faktor-Faktor yang Mempengaruhinya, (jakarta: pt. rineka cipta, 2013), h. 180

${ }^{13}$ Syaiful bahri djamarah, psikologi belajar (Jakarta: Renika cipta), h.166

${ }^{14}$ Op cit, h. 180

${ }^{15}$ Safari, Penulisan Butir Soal Berdasarkan Penilaian Berbasis Kompetensi, (Jakarta: Assosisai Pengawasan Sekolah Indonesia, 2005), Cetakan Ke-2, h.111.
}

\begin{tabular}{|c|l|l|}
\hline No & \multicolumn{1}{|c|}{ Dimensi } & \multicolumn{1}{c|}{ Indikator } \\
\hline 1. & Kesukaan & $\begin{array}{l}\text { Gairah } \\
\text { Inisiatif }\end{array}$ \\
\hline 2. & Ketertarikan & $\begin{array}{l}\text { Responsif } \\
\text { Kesegaran }\end{array}$ \\
\hline 3. & Perhatian & $\begin{array}{l}\text { Konsentrasi } \\
\text { Ketelitian }\end{array}$ \\
\hline 4. & Keterlibatan & $\begin{array}{l}\text { Kemauaan } \\
\text { Keuletan } \\
\text { Kerja keras }\end{array}$ \\
\hline
\end{tabular}

Menurut hemat peneliti teori di atas masih bersifat umum maka peneliti perlu menjelaskan lagi yang sifatnya lebih kongkrit yaitu:

a. Kesukaan

1) Gairah (semangat). Menurut kamus lengkap bahasa Indonesia menyebutkan ada beberapa makna dari kata gairah ini, dan salah satunya "bersemangat". ${ }^{16}$ Jadi dapat di artikan makna gairah ini adalah dorongan dari dalam diiringi dengan semangat yang tinggi dan di ikuti dengan melakukannya

2) Inisiatif. Maksud dari inisiatif ini adalah daya untuk melakukan suatu pekerjaan tanpa menunggu intervensi atau suruhan orang lain. $^{17}$

b. Ketertarikan

1) Responsif. Dalam kamus besar bahasa Indonesia responsif bermakna dengan tanggapan, tergugah hati. ${ }^{18}$

2) Kesegaran. Kesegaran yang di maksud adalah keadaan nyaman yang mendukung suatu kegiatan

${ }^{16}$ Pusat bahasa, Kamus Lengkap Bahasa Indonesia, (depertemen pendidikan nasional), h.405

${ }^{17}$ Ibid. $h .537$

${ }^{18}$ Ibid., h. 2104 
berjalan dengan lancar tanpa ada gangguan. ${ }^{19}$

c. Perhatian

1) Konsentrasi. Konsentrasi adalah pemusatan perhatian pada saat melaksanakan aktivitas belajar. Pada setiap pembalajaran atau kegiatan lainya di tuntut untuk konsentrasi agar informasi dan ilmu pengetahuan yang di transfer bisa di di pahami dengan baik. ${ }^{20}$ Perhatian yang konsentrasitif adalah seseorang yang dapat memusatkan pikiran,perasaan maupun kemauannya kepada satu objek saja. ${ }^{21}$ Konsentrasi yang di maksud penulis disini adalah pemusatan baik itu pemikirannya ataupun perilakunya dalam suatu kagiatan.

2) Ketelitian. Ketelitian sinomin dengan kata kecermatan jadi dapat di artikan kecermatan dalam memahami suatu masalah dan jalan penyelesaiannya ${ }^{22}$

d. Keterlibatan

1) Kemauan. Kamauan adalah Dorongan kehendak yang terarah pada tujuan-tujuan hidup tertentu dan di kendalikan dengan pertimbangan akal budi, dan dari kemauan timbullah dinamika dan aktivitas manusia. $^{23}$

2) Keuletan. Keuletan atau tidak mudah putus asa yang di sertai

${ }^{19}$ Ibid., h.1240

${ }^{20}$ Muhammad Takdir Ilahi, Revitalisasi Pendidikan Berbasis Moral, (Jogjakarta: Arruz Media, 2012,) h.95

${ }^{21}$ Kartini Kartono, Psikologi Umum

(Bandung: Mandar Maju,1995,) h.27

${ }^{22}$ OpCit., h. 1428

${ }^{23}$ Makmum Kharani, Op.Cit., h. 170 kemauan yang tinggi untuk mencapai tujuan yang di inginkan. $^{24}$

Menurut M.Dalyono ada tidaknya minat siswa dapat di lihat dari cara :

a. Siswa di siplin mengikuti pelajaran

b. Siswa melengkapi catatan pelajaran

c. Siswa memperhatikan pelajaran yang di sampaikan oleh guru dalam proses pembelajaran $^{25}$

Kecendrungan untuk melakukan suatu aktivitas tidak lepas dari minat,minat menjadi pengaruh besar terhadap keberhasilan akan apa yang di lakukan. Menurut Sumanto, dalam bukunya Psikologi Umum, terdapat ciri minat secara umum yaitu:

a. Adanya perhatian dan harapan yang besar

b. Beroreantasi pada keberhasilan

c. Mempunyai kebanggaan

d. Kesediaan untuk berusaha

e. Mempunyai pertimbangan yang positif. ${ }^{26}$

Pandangan para ahli tentang minat di maknai secara beragam, berbeda dan sesuai dengan cara dan sudut pandang masing-masing. Menurut beberapa ahli minat mengandung unsur-unsur sebagai berikut :

a. Minat adalah suatu gejala psikologis

b. Adanya pemusatan perhatian, perasaan dan pikiran dari subyek karena tertarik

c. Adanya perasaan senang dari objek yang menjadi sasaran Adanya

\footnotetext{
${ }^{24}$ Op.Cit., h. 1523

${ }^{25}$ M.Dalyono, Psikologi Pendidikan, (Jakarta: Rineka, Cipta 2010), h.235.

${ }^{26}$ Sumanto, Op Cit, h.161.
} 
d. Adanya kemauan kecendrungan pada diri sabyek untuk melakukan kegiatan guna mencapai tujuan. ${ }^{27}$

Setiap individu memiliki minat yang berbeda pula, minat yang dimiliki oleh individu berkaitan dengan keperibadian yang dimilki oleh individu tersebut.

a. Realistis. Orang realistis umumnya mapan, kasar, praktis, berfisik kuat dan sering sangat atletis, memiliki koordinasi otot yang baik dan terampil. Akan tetapi kurang mampu menggunakan medium komunikasi verbal dan kurang memiliki keterampilan berkomuni- kasi dengan orang lain. Orang realistis menyukai pekerjaan montir, insinyur, ahli listrik, ikan dan kehidupan satwa liar, operator alat berat dan perencana alat. $^{28}$

b. Investigative. Orang investigative termasuk orang yang berorientasi keilmuan. Mereka umumnya berorientasi pada tugas, introspektif, dan asosial, lebih menyukai memikirkan sesuatu daripada melaksanakannya, memiliki dorongan kuat untuk memahami alam, menyukai tugas-tugas yang tidak pasti, suka bekerja sendirian, kurang pemahaman dalam kepemimpinan akademis dan intelektualnya, menyatakan diri sendiri sebagai analisis, selalu ingin tahu, bebas dan bersyarat dan kurang menyukai pekerjaan yang berulang. Kecendrungan pekerjaan yang disukai termasuk ahli perbintangan, biologi, binatang, dan ahli jiwa. ${ }^{29}$

c. Artistik. Orang artistik menyukai halhal yang tidak terstruktur, bebas, memiliki kesempatan bereaksi, sangat membutuhkan suasana yang dpat mengekspresi kan sesuatu secara individual, sangat kreatif dalam bidang seni dan usik. Kecendrungan pekerjaan yang disenangi adalah pengarang, musisi, penata pentas, konduktor konser, dan lain-lain. ${ }^{30}$

d. Sosial. Tipe ini dapat bergaul, bertanggung jawab, berkemanusia an, dan sering alim, suka bekerja dalam kelompok, senang menjadi pusat perhatian kelompok, memiliki kemampuan verbal, terampil bergaul, menghindari pemecahan masalah secara intelektual, suka memecahkan masalah yang ada kaitannya dengan perasaan, menyukai kegiatan mengimformasikan, melatih dan mengajar. Pekerjaan yang disukai menjadi pekerja sosial, pendeta, ulama dan guru. ${ }^{31}$

e. Enterprising. Tipe ini cendrung menguasai atau memimpin orang lain, memiliki keterampilan verbal untuk bedagang, memiliki kemampuan untuk mencapai tujuan organisasi, agresif, percaya diri dan umumnya sangat aktif. Pekerjaan yang disukai termasuk pimpinan perusahaan, pedagang dan lain-lain. ${ }^{32}$

f. Konvensional. Orang konvensional menyukai lingkungan yang sangat tertib, menyenangi komunikasi
${ }^{27}$ Makmum Khairani, Op Cit., h.137.

${ }^{28}$ Djaali, Psikologi Pendidikan, (Jakarta:PT Bumi Aksaa,2013), h.123
${ }^{29}$ Ibid.,

${ }^{30}$ Ibid., h.123-124

${ }^{31}$ Ibid.,

${ }^{32}$ Ibid., 
verbal, senang kegiatan yang berhubungan dengan angka, sangat afektif menyelesaikan tugas yang berstruktur tetapi menghindari situasi yang tidak menentu, menyatakan diri orang yang setia, patuh, praktis, tenang tertib, efesien: mereka mengidentifikasi kan diri dengan kekuasaan dan materi. Pekerjaan yang disukai antara lain sebagai akuntan, ahli tata buku, ahli pemeriksa barang dan pimpinan armada angkutan. ${ }^{33}$

Semua pekerjaan yang dilakukan oleh individu pada awalnya dipilih oleh individu tersebut berdasarkan dari minat. Minat yang ada dalam diri individu sangat menentukan kualitas yang dikerjakan oleh individu itu, semakin tinggi minat yang ada didalam diri individu maka semakin baik kualitas pekerjaanya.

Menurut crow and crow yang dikutip dari buku psikologi belajar karangan H.Makmum Khairani menyebutkan bahwa Minat pada hakikat nya merupakan sebab akibat dari pengalaman. Minat berkembang sebagai hasil dari pada suatu kegiatan dan akan menjadi sebab di pakai lagi dalam kegiatan yang sama.

Faktor-faktor tersebut sebagai berikut:

a. The Factor Inner Urge. Rangsangan yang datang dari lingkungan sekitar atau ruang lingkup yang sesuai dengan keinginan atau kebutuhan seseorang akan mudah menimbul kan minat, dalam hal ini seseorang mempunyai hasrat ingin tahu terhadap ilmu pengetahuan. ${ }^{34}$ Jadi lingkungan sekitar menjadi pengaruh yang besar, bisa jadi pengaruh dari keluarga atau dari teman.

b. The Factor Of Sosial Motive. Minat seseorang terhadap obyek atau sesuatu hal.Disamping itu juga dipengaruhi oleh faktor dalam diri manusia dan oleh motif sosial. ${ }^{35}$ Faktor yang di maksud adalah berminat dalam melakukan suatu kegiatan,yang di pengaruhi oleh faktor dari dalam diri manusia dan keingian sosial yang tinggi. Misalnya mengikuti kegiatan ekstrakurekuler dengan senang hati juga agar menjadi terkenal di lingkungannya.

c. Emosional Factor. Faktor perasaan dan emosi ini mempunyai pengaruh terhadap objek misalnya perjalanan sukses yang di pakai individu dalam suatu kegiatan tertentu dapat pula membangkitkan perasaan senang dan dapat menambah semangat. Atau kuatnya minat dalam kegiatan tersebut.

Menurut Dewa Ketut Sukardi, yang mengutip pendapat Carl Safran, bahwa ada tiga cara yang dapat di gunakan untuk menentukan minat, yaitu:

a. Minat yang di ekspresikan/ Expressed Interest. Seseorang dapat mengungkapkan minat atau pilihanya dengan kata-kata tertentu.

b. Minat yang di wujudkan / Menifest Interest. Seseorang dapat mengungkapkan bukan melalui kata kata melainkan dengan tindakan atau 
perbuatan, yaitu ikut serta dan berperan aktif dalam suatu kegiatan

c. Minat yang di inventariskan/ Inventoral Interest. Seseorang menilai minatnya agar dapat di ukur dengan menjawab terhadap sejumlah pertanyaan tertentu atau urutan pilihannya atau kelompok aktivitas tertentu. $^{36}$

\section{Seminar Proposal}

Seminar proposal terdiri dari dua suku kata yaitu seminar dan proposal. Menurut kamus lengkap bahasa Indonesia seminar adalah pertemuan yang dihadiri oleh beberapa peserta untuk membicarakan suatu masalah. ${ }^{37}$

Sedangkan proposal berasal dari bahasa Inggris yaitu 'Propose' yang berarti mengusulkan. ${ }^{38} \mathrm{Jadi}$ dapat disimpulkan seminar proposal adalah suatu kegiatan yang merupakan pertemuan yang dihadiri oleh beberapa peserta untuk membicarakan suatu masalah yang sedang diusulkan.

Menurut Adnan Mahdi dan Mujahidin dalam Bukunya Panduan Penelitian Praktis Untuk Menyusun Skripsi, Tesis dan Disertasi menyebutkan bahwa yang di maksud dengan seminar proposal adalah:

Seminar proposal merupakan salah satu kegiatan yang dikhususkan untuk membahas rencana penelitian yang telah di susun oleh mahasiswa. Kegiatan seminar ini biasanya di jadwalkan oleh program studi atau

\footnotetext{
${ }^{36}$ Ibid., h.141.

${ }^{37}$ Tim Prima Pena, Kamus Lengkap Bahasa Indonesia, (Gita Media Press, T. Th), h.585

${ }^{38}$ Andre Ardiyansah, Kamus Lenkap Yunior 55 Milyar, (Surabaya: Pustaka Agung Harapan, Tth), h. 125
}

jurusan setelah semua persyaratan seminar dipenuhi oleh mahasiswa. ${ }^{39}$ Kegiatan seminar biasanya narasumber menyajikan sebuah materi kemudian dari materi tersebut timbul sebuah permasalahan yang akan dijadikan bahan perbincangan. Kegiatan seminar proposal hingga kini banyak dipakai di berbagai kalangan dari pemerintahan, pembisnis sampai kepada pendidikan. Dunia pendidikan salah satu kegiatan seminar proposal yang paling popular adalah seminar proposal penelitian untuk tugas akhir menyelesaikan skripsi bagi mahasiswa strata satu (S1).

Proposal penelitian dalam dunia ilmiah (pendidikan) yang disusun oleh seorang peneliti atau mahasiswa yang akan membuat penelitian. proposal adalah suatu rancangan desain penelitian (usulan penelitian) yang akan dilakukan oleh seorang peneliti tentang suatu bahan penelitian. Bentuk proposal penelitian ini biasanya memiliki suatu bentuk dengan berbagai standar tertentu seperti penggunaan bahasa, tanda baca, kutipan dan lain-lain.

Menurut Sugiyono dalam bukunya Cara Mudah Menyusun Skripsi, Tesis dan Disertasi menyebutkan bahwa proposal penelitian merupakan rancangan penelitian yang berisi langkah langkah rasional dan sistematis yang akan dilakukan dalam penelitian. ${ }^{40}$

a. Pelaksanaan seminar proposal

${ }^{39}$ Adnan Mahdi \& Mujahidin, Panduan Penelitian Praktis Untuk Menyusun Skripsi, Tesis, dan Disertasi, (Bandung: Alfabet, 2014), h. 41

${ }^{40}$ Sugiyono, Cara Mudah Menyusun Skipsi, Tesis, dan Disertasi, (Bandung: Alpabet, 2016, Cet.ke-4), h. 404. 
Pada pelaksanaan seminar Proposal, yang perlu di perhatikan dan dipersiap kan antara lain:

1) Berita Acara Seminar Proposal

2) Lampiran Daftar Hadir Atau absensi peserta Seminar Proposal

3) Membawa From lampiran kartu kendali seminar proposal,(jika perlu) bagi audience sebagai bukti pernah menghadiri.

4) File untuk dipresentasikan

5) Audience paling sedikit sebanyak 7 orang mahasiswa.

Menghadiri seminar proposal banyak manfaatnya antara lain:

a. Mengasah Ketelitian. Biasanya dalam seminar proposal moderator memberikan sesi tanya jawab atau saran kritik dan itu semua sangat di butuhkan oleh peserta seminar, namun untuk mengisi sesi ini perlu bagi yang menghadiri untuk membaca keseluruhan yang di sajikan secara teliti sehingga menemukan kesalahan -kesalahan kecil yang kadang tidak sengaja di buat oleh penyaji.

b. Mempertajam Nalar dan Sikap Kritis. Menghadiri seminar akan terbiasa berpikir kritis dan sistematis dan secara tidak langsung pemikiran akan terbuka dan mengetahui cara meneliti yang masuk akal (logis).

c. Memperkaya Wawasan Masalah . Menghadiri seminar proposal akan menembah pengetahuan, dan memperkaya wawasan masalah. Karena masalah menjadi dasar dari penelitian

d. Melatih Mental. Selain dapat memperkaya wawasan masalah juga melatih mental, dengan seringnya menghadiri kegiatan seminar serta ikut berpartisifasi didalamnya baik itu berupa memberikan pertanyaan ataupun arahan atau saran

e. Mendapat Pengetahuan Baru. Pengetahuan yang bisa di dapat di lembaga formal (perkuliahan) juga bisa di luar formal melalui kegiatankegiatan tertentu di luar perkuliahan salah satunya dengan menghadiri seminar proposal.

f. Mengisi Waktu Luang. Mengisi waktu luang dengan menghadiri kegiatan yang bermanfaat seperti menghadiri seminar proposal. ${ }^{41}$

\section{Minat Mahasiswa Dalam Menghadiri Kegiatan Seminar Proposal}

Langkah terbaik sebelum seminar proposal adalah selalu datang menghadiri kegiatan seminar proposal yang di lakukan oleh mahasiswa tingkat atau mahasiswa senior. Adapun yang perlu diketahui tujuan dari langkah ini adalah untuk mendapat gambaran bagaimana sebenarnya pelaksanaan seminar proposal tersebut. ${ }^{42}$

Sejatinya sebagai mahasiswa yang mempunyai tanggung jawab besar terhadap pendidikannya maka mahasiswa harus mempunyai kesadaran untuk tetap mengembangkan ilmu pengetahuan yang ada dalam dirinya. Pada akhirnya sebagai seorang mahasiswa mereka harus berbenah diri untuk mampu bersaing dengan individu yang lain.

Kegiatan seminar proposal adalah salah satu bentuk kegiatan akademik

\footnotetext{
${ }^{41}$ www, hipwee.com/list/6- alasan kenapa kamu harus menghadiri seminar proposal-atau seminar hasil/.2016/11/30 16:00 wib

${ }^{42}$ Adnan Mahdi Mujahidin, Op.Cit., h.42
} 
yang ada di kampus guna untuk mengembangkan ilmu pengetahuan yang ada pada diri mahasiswa, selain dari itu kegiatan seminar proposal juga bertujuan agar mahasiswa mampu berpikir kritis dan mampu berkomunikasi secara epektif dan efesien.

Oleh sebab itu mahasiswa yang berminat menghadiri kegiatan seminar proposal ditandai dengan:

a. Bergairah (bersemangat) untuk menghadiri kegiatan seminar proposal

b. Menghadiri kegiatan seminar atas inisiatif/keinginan sendiri

c. Tertarik untuk menghadiri kegiatan seminar proposal

d. Mengajukan pertanyaan kegiatan seminar proposal

e. Konsentrasi terhadap kegiatan seminar yang sedang berlangsung

f. Memahami setiap isi proposal yang di paparkan

g. Mencatat penjelasan dosen pembimbing ketika seminar proposal

h. Berusaha tepat waktu untuk menghadiri kegiatan seminar proposal

i. Memberiakan argumennya terhadap permasalahan yang belum terselesai kan

j. Kemauan memberi saran atau masukan terhadapisi proposal penelitian

Ketika mahasiswa yang menjadi audiensi kegiatan seminar telah melakukan 10 komponen diatas maka mahasiswa tersebut mempunyai minat yang tinggi terhadap kegiatan seminar proposal, dan tujuan kegiatan seminar proposalpun secara tidak langsung akan tercapai.

\section{B. METODOLOGI}

Subjek didalam penelitian ini adalah Mahasiswa Sekolah Tinggi Agama Islam Auliaurrasyidin Tembilahan. Adapun objek dalam penelitian ini adalah Minat Mahasiswa Dalam Menghadiri Kegiatan Seminar Proposal di Auliaurrasyidin Tembilahan. Populasi dalam penelitian ini adalah mahasiswa SekolahTinggi Agama Islam Auliaurrasyidin Tembilahan dari semesterVII, IX, XI, XIII termasuk laki-laki dan perempuan dari Prodi PAI dan PGMI sebanyak 92 mahasiswa. Adapun teknik pengumpul an data yang digunakan oleh peneliti adalah: Angket, Wawancara dan dokumentasi. Teknik Analisa data dalam penelitian ini menggunakan teknik deskriptif analitik persentasi. Dalam bentuk deskriptip analitik untuk menggunakan persentasi maka diguna kan rumus:

$$
\mathrm{P}=\mathrm{F} / \mathrm{N} \times 100 \%
$$

Keterangan:

$\mathrm{P}=$ Angka persentasi

$\mathrm{F}=$ Frekuensi

$\mathrm{N}=$ jumlah individu.

Sedangkan standar kategori yang digunakan adalah:
$80-100 \%$
: Sangat tinggi
$61-80 \%$
: Tinggi
$40-60 \%$
: Cukup tinggi
$21-40 \%$
: Rendah
$0-20 \%$
: Rendah sekali

\section{PEMBAHASAN}

\section{Penyajian Data Hasil Angket}

Dalam penelitian angket disebarkan kepada 92 mahasiswa yang menjadi sampel penelitian. Hasil angket tersebut disajikan dalam table rekapitulasi di bawah ini: 


\begin{tabular}{|c|c|c|c|c|c|c|}
\hline \multirow{2}{*}{ No } & \multicolumn{6}{|c|}{ Alternatif Jawaban } \\
\cline { 2 - 7 } & \multicolumn{2}{|c|}{$\mathbf{A}$} & \multicolumn{1}{|c|}{ B } & \multicolumn{1}{|c|}{ C } \\
\cline { 2 - 7 } & $\mathbf{F}$ & $\mathbf{\%}$ & $\mathbf{F}$ & $\mathbf{\%}$ & $\mathbf{F}$ & $\mathbf{\%}$ \\
\hline 1 & 39 & 42,39 & 49 & 53,26 & 4 & 4,34 \\
\hline 2 & 33 & 35,87 & 53 & 57,06 & 5 & 5,43 \\
\hline 3 & 21 & 22,82 & 64 & 69,56 & 7 & 7,61 \\
\hline 4 & 17 & 18,47 & 59 & 64,13 & 16 & 17,39 \\
\hline 5 & 45 & 48,91 & 45 & 48,91 & 2 & 2,17 \\
\hline 6 & 38 & 52,17 & 48 & 52,17 & 6 & 6,5 \\
\hline 7 & 19 & 20,65 & 56 & 60,87 & 17 & 18,48 \\
\hline 8 & 41 & 44,56 & 43 & 46,73 & 8 & 8,69 \\
\hline 9 & 3 & 3,26 & 71 & 77,17 & 18 & 19,56 \\
\hline 10 & 13 & 14,13 & 52 & 56,52 & 27 & 29,35 \\
\hline
\end{tabular}

Dari tabel rekapitulasi di atas dapat di ketahui jawaban masing masing opsional adalah sebagai berikut:

Opsional A :Selalu :269

Opsional B :kadang-kadang :540

Opsional C :Tidak pernah $: 110$

Sehingga jumlah $N=269+540+$ $110=919$

Selanjutnya masing masing jawaban di berikan skoralternatif, jawaban selalu diberi skor 3, alternatif jawaban kadang kadang diberi skor 2, alternatif jawaban tidak pernah diberi skor 1 .

Dari penskoran didapat hasil sebagai berikut:

$$
\begin{array}{ll}
\text { Opsional } & \mathrm{A}=269 \times 3=887 \\
\text { Opsional } & \mathrm{B}=540 \times 2=1080 \\
\text { Opsional } & \mathrm{C}=110 \times 1=\frac{110}{2077}
\end{array}
$$

Sehingga jumlah $\mathrm{F}=887+1080+110$ $=2077$

Dengan demikian diketahui bahwa $\mathrm{F}=$ 2077, sedangkan:

$\mathrm{N}=$ Jumlah Populasi $\mathrm{x}$ Jumlah Pertanyaan pada Angket $x$ Skor Tertinggi $=92 \times 10 \times 3=2760$

Selanjutnya untuk mengetahui minat mahasiswa dalam menghadiri seminar proposal di Sekolah Tinggi Agama Islam (STAI) Auliaurrasyidin Tembilahan Kabupaten Indragiri Hilir, digunakan rumus :

$$
\begin{aligned}
& \mathrm{P}=\frac{\mathrm{F}}{\mathrm{N}} \times 100 \% \\
& \mathrm{P}=\frac{2077}{2760} \times 100 \% \\
& \mathrm{P}=75,25 \%
\end{aligned}
$$

Dengan demikian dapat di simpulkan bahwa minat mahasiswa dalam menghadiri kegiatan seminar proposal di Sekolah Tinggi Agama Islam (STAI) Auliaurrasyidin Tembilahan Kabupaten Indragiri Hilir mencapai angka 75,25 dan dikategorikan "Tinggi" karena angka terletak pada interval 60-80\%

\section{Penyajian Data Hasil Wawancara}

Untuk mendukung data hasil angket, penulis melakukan wawancara kepadaorang responden. Data hasil wawancara tersebut disajikan secara berurutan di bawah ini:

a. Apa alasan saudara untuk mengadiri kegiatan seminar proposal?

"Saya ikut seminar proposal ini untuk menambah wawasan saya dalam pembuatan karya ilmiah"43

"Menghadiri seminar proposal tidak ada unsur kerugian saya senang mengikuti atau mengadiri karena dengan mengadiri kita dapat mendengar penjelasan seputar penyusunan proposal baik dari penyeminar proposalnya atau pun penjelasan dosen pembimbing". ${ }^{4}$

"Alasan saya menghadiri seminar proposal ini pertama untuk

${ }^{43}$ Siti Fatimah, Mahasiswa Semester IX/A Jurusan PAI, Wawancara Pribadi, STAI Auliurrasyidin Tembilahan, 18 Oktober,2016

${ }^{44}$ Nurlela, Mahasiswa Semester IX/D Jurusan PAI, Wawancara Pribadi, STAI Auliurrasyidin Tembilahan, 27 Oktober 2015 
menambah ilmu pengetahuan tentang pembuatan karya ilmiah berupa proposal penelitian dan juga terkadang untuk memenuhi kebutuhan minimal audiensi dalam kegiatan seminar proposal tersebut" 45

b. Apakah ada hal lain yang mendukung saudara untuk mengadiri kegiatan seminar proposal?

"Memang menghadiri seminar ini tidak ada unsur paksaan tapi tekadang saya menghadiri seminar dengan inisiatif sendiri dan juga kadang di ajak teman". ${ }^{46}$

"saya menghadiri kegiatan seminar ini kadang-kadang dengan niat sendiri kadang-kadang di ajak teman, dalam kegiatan seminar itu saya suka penjelasan penjelasan dari masalah yang belum bisa di pecahkan dan bagi penyeminar meminta untuk menyampaikan pendapat,saran,atau ada yang kurang pas dalam proposal itu kepada audiensi maupun dosen pembimbing sebagai penjelas". ${ }^{47}$

c. Bagaimana meningkatkan keantusias an saudara untuk tetap menghadiri kegiatan seminar proposal?

"saya pikir bahwa kegiatan seminar ini adalah sebagai tempat atau wadah penyampaian ilmu yang telah pelajari melalui teori yang ada, khususnya tentang metodologi penelitian, nah melalui seminar proposal ini penyeminar menyampaikan isi dari proposalnya sedangkan saya

\footnotetext{
${ }^{45}$ Imasniam, Mahasiswa Semester IX/D Jurusan PAI, Wawancara Pribadi, STAI Auliurrasyidin Tembilahan, 2 November 2016

${ }^{46}$ Herma Aziz, Mahasiswa Semester 1X/B Jurusan PAI, Wawancara Pribadi, STAI Auliurrasyidin Tembilahan, 5 November 2016

${ }^{47}$ Liska susanti, Mahasiswa Semester IX/E Jurusan PAI, Wawancara Pribadi, STAI Auliurrasyidin Tembilahan, 11 November 2016
}

mendengarkan dengan baik,dan yakin bahwa apa yang di sampaikan nya itu adalah hal yang penting". ${ }^{48}$

"Memang terkadang sulit karena mungkin ada kesibukan atau hal lain yang akan di lakukan tapi bagi saya kalo hanya menghadiri saja tidak ada ruginya selain membantu sesama teman tentu kita dapat pengalaman di dalamnya dan meyakinkan diri bahwa menghadiri seminar itu penting". 49

d. Apakah tempat yang nyaman mempengaruhi saudara untuk menghadiri kegiatan seminar?

"Ya suasana yang kondusif mendukung kenyamanan dalam kegiatan seminar ini". 50

"iya karena tempat itu suatu faktor pendukung keberhasilan dalam belajar dan jika tempatnya tidak nyaman aan menghambat proses kegiatan seminar tersebut." $" 51$

\section{KESIMPULAN}

Berdasarkan hasil hasil angket yang di lakukan oleh penulis dapat di simpulkan Bahwa Minat Mahasiswa Dalam Menghadiri Kegiatan Seminat Proposal di Sekolah Tinggi Agama Islam Auliaurrasyidin Tembilahan Kabupaten Indragiri Hilir dikategorikan "Tinggi" karenamencapaiangkadenganpersentase 7 5,25 . karena angka terletak pada interval $61 \%-80 \%$

${ }^{48}$ Irma Lismawati, Mahasiswa Jurusan PAI/E Semester IX, Wawancara Pribadi, STAI Auliurrasyidin Tembilahan, 5 November 2016

${ }^{49}$ Muzi Hastuti, Mahasiswa Jurusan PAI/F Semester IX, Wawancara Pribadi, STAI Auliurrasyidin Tembilahan, 5 November 2016

${ }^{50}$ Selamat, Mahasiswa Jurusan PGMI Semester IX, Wawancara Pribadi, STAI Auliurrasyidin Tembilahan, 5 November 2016

${ }^{51}$ Dedy Kurniawan, Mahasiswa Jurusan PAI Semester IX, Wawancara Pribadi, STAI Auliurrasyidin Tembilahan, 14 November 2016 
1. Berdasarkan wawancara yang di lakukan oleh peneliti kepada mahasiswa maka dapat di simpulkan minat mahasiswa dalam menghadiri seminar ini

2. Terdapat faktor yang mempengaruhi dalam kegiatan seminar proposal, berikut ada 3 faktor mempengaruhi minat yang menjadi landasan penulis faktor-faktor yang mempengaruhi minat tersebut sebagai berikut:

a. The Factor Inner Urge. Rangsangan yang datang dari lingkungan sekitar atau ruang lingkup yang sesuai dengan keinginan atau kebutuhan seseorang akan mudah menimbulkan minat, dalam hal ini seseorang mempunyai hasrat ingin tahu terhadap ilmu pengetahuan. Jadi lingkungan sekita menjadi pengaruh yang besar,bisa jadi pengaruh dari keluarga atau dari teman.

b. The Factor Of Sosial Motive. Minat seseorang terhadap obyek atau sesuatu hal. Di samping itu juga di pengaruhi oleh faktor dalam diri manusia dan oleh motif sosial. Faktor yang di maksud adalah berminat dalam melakukan suatu kegiatan,yang di pengaruhi oleh faktor dari dalam diri manusia dan keingian sosial yang tinggi. Misalnya mengikuti kegiatan ekstrakurekuler dengan senang hati juga agar menjadi terkenal di lingkungannya

c. Emosional Factor. Faktor perasaan dan emosi ini mempunyai pengaruh terhadap objek misalnya perjalanan sukses yang di pakai individu dalam suatu kegiatan tertentu dapat pula membangkitkan perasaan senang dan dapat menambah semangat. Atau kuatnya minat dalam kegiatan tersebut. Faktor-faktor yang telah peneliti sebutkan sebagai teori dan sesuai dengan wawancara yang penulis lakukan penuli dapat simpulkan bahwa minat mahasiswa dalam menghadiri kegiatan seminar proposal ini sudah cukup baik, hanya saja ada faktor lingkungan menjadikan beberapa mahasiswa yang melakukan kegiatan itu di dorong oleh teman tidak dengan inisistif sendiri.

\section{REFERENSI}

Anas Sudijono, (2008, Pengantar Statistik Pendidikan, Jakarta: PT Raja Grapindo Persada.

Adnan Mahdi \& Mujahidin, (2014), Panduan Penelitian Praktis Untuk Menyusun Skripsi, Tesis, Dan Disertasi, Bandung: Alfabet.

Abdul Rahman Shaleh Dan Muhbib Abdul Wahab, (2014), Psikologi Suatu Pengantar Dalam Perspektif Islam, Jakarta: Prenada Media.

Andre Ardiyansyah, (Tth), Kamus

Lengkap Yunior 55, Surabaya:

Pustaka Agung Harapan.

Bima Walgito (1981), Bimbingan Dan Penyaluran Di Sekolah, Yogyakarta: Fakultas F Isikolgi Ugm.

Djaali, (2013), Psikologi Pendidikan, Jakarta: Pt Bui Aksaa 
Hasan Basri, (2010), Filsafat Pendidikan Islam, Bandung: Pustaka Setia

W.C. Witherington, (1985), Psikologi Pendidikan Jakarta: Aksara Baru

Nurul Zuriah (2006), Metodologi Penelitian Sosial dan Pendidikan Teori-Aplikasi, Jakarta: Bumi Aksara.

Jhon M. Echols dan Hasan Shadily, (2000), Kamus Inggris Indonesia, Jakarta: PT Gramedia.

Kusuma Wijaya dan Dewi Tagana Dedi, (2011), Mengenal Penelitian Tindakan Kelas, Jakarta: PT Indeks

Kartini Kartono, (1995), Psikologi Umum, (Bandung: Mandar Maju.

Muhibbin Syah, M. Ed, (2001), Psikologi Belajar, Jakarta: Logos Wacan Ilmu.

M.Dalyono, (2010), Psikologi Pendidikan, Jakarta: Rineka, Cipta.

Makmum Khairani, (2013), Psikologi Belajar, Yogyakarta: Aswaja Pressindo.

Muhammad Takdir Ilahi, (2012), Revitalisasi Pendidikan Berbasis Moral, Jogjakarta: Arruz Media,

M Kasir Ibrahim, (T, Th) Kamus Arab, Surabaya: Apollo.

Moh.Uzer Usman, (2010), Menjadi Guru Professional, Bandung: Remaja Rosda Karya.

Perpustakaan Nasional, (2010), Peraturan Pemerintah Nomor Tahun 17 Tahun 2010 Tentan Pengeolaan Dan Penyelenggaraan Pendidikan, Yogyakarta: Pustaka Timur

Psikologi, (2004), Modul Orientasi Pembekalan Calon PNS Proyak Pembibitan Calon Tenaga Kependidikan Biro Kepegawaian Secretariat Jendral Depertemen Agama Republik Indonesia

Riduan, (2011), Belajar Mudah Penelitian Untuk Guru Karyawan Dan Penelitian Pemula, Bandung: Alfa Mata
Suharsimi Arikunto, (2006), Prosedur Penelitian Suatu Pendekatan Praktek, Jakarta: Rineka Cipta.

Sapiah Faisal, (2003), Format Format Penelitian Sosial, Jakarta: PT. Grafindo Persada.

Sugiyono, (2016), Cara Mudah Menyusun Skipsi, Tesis, dan Disertasi, Bandung: Alpabet, Cet.ke-4.

Sumanto, (2014), Psikologi Umum, (Yogyakarta:PT Buku Seru.

Slameto, (2013), Belajar Dan FaktorFaktor Yang Mempengaruhinya, (Jakarta: PT. Rineka Cipta,

Syaiful Bahri Djamarah, (2008), Psikologi Belajar Jakarta: Renika Cipta),

Safari, (2005), Penulisan Butir Soal Berdasarkan Penilaian Berbasis Kompetensi, Jakarta: Assosisai Pengawasan Sekolah Indonesia. Cetakan $\mathrm{Ke}-2$.

Sadirman A.M, (2003), Intraksi Motivasi Belajar Mengajar, Jakarta: PT Grafindo Persada.

Trianto, (2011), Mendesain Model Pembelajaran Inovatif Progresif Jakarta: Kencana Prenada Media Group

Tim Prema Pena, (T. Th), Kamus Lengkap Besar Bahasa Indonesia, Gita Media Press

W.J. Spoerwadarminta, (2007), Kamus Umum Bahasa Indonesia, (Jakarta: BalaiPustaka.

Www.Hipwee.Com/List/6-

AlasanKenapa Kamu Harus Menghadiri Seminar Proposal-Atau Seminar Hasil/ .2016/11/30 16:00 Wib

Zainal Arifin, (2007), Penelitian Pendidikan Metode Dan Paradigma Baru, Jakarta: Rosda Karya. 